\title{
MANFAAT EMOTIONAL INTELLIGENCE BAGI PENGAJAR DALAM PROSES BELAJAR MENGAJAR
}

\author{
Astrini \\ Jurusan Psikologi, Fakultas Psikologi, Bina Nusantara University, \\ Jln. Kemanggisan Ilir III No 45, Kemanggisan, Palmerah, Jakarta Barat 11480 \\ astrini@binus.edu
}

\begin{abstract}
This paper contains a theoretical overview of Emotional Intelligence or emotional intelligence that can be applied in teaching and learning. The application of emotional intelligence is not only beneficial to create quality graduates but is also useful for self-development of teachers. Emotional intelligence can be developed by the faculty including the development of self-awareness of their feelings experience, acceptance and management of feelings, relationships built with students and also the ability to create a conducive learning environment for students ready to learn.
\end{abstract}

Keywords: emotional intelligence, teaching and learning process

\begin{abstract}
ABSTRAK
Makalah ini berisi tinjauan teoritis mengenai Emotional Intelligence atau kecerdasan emosi yang dapat diaplikasikan dalam proses belajar mengajar. Aplikasi dari kecerdasan emosi ini bukan hanya bermanfaat untuk menciptakan lulusan yang baik namun juga bermanfaat untuk pengembangan diri para pengajar. Kecerdasan emosi yang dapat dikembangkan oleh pengajar mencakup pengembangan kesadaran diri akan perasaanperasaan yang dialami, penerimaan dan pengelolaan perasaan, relasi yang dibangun dengan peserta didik dan juga kemampuan untuk menciptakan lingkungan belajar yang kondusif agar peserta didik siap untuk menerima pelajaran.
\end{abstract}

Kata kunci: emotional intelligence, proses belajar mengajar 


\section{PENDAHULUAN}

Dalam dunia pendidikan khususnya pendidikan formal, kegiatan belajar mengajar merupakan inti dari proses pembelajaran yang didasarkan pada kurikulum yang sudah ditetapkan. Secara umum mutu pendidikan yang dicerminkan oleh mutu lulusan dipengaruhi oleh mutu kegiatan belajar mengajar, jika mutu kegiatan belajar mengajar bagus maka mutu lulusannya juga akan bagus. Dalam kegiatan belajar mengajar, pengajar berperan sebagai individu yang memberikan pengajaran berdasarkan kurikulum atau tujuan tertentu sesuai dengan perkembangan peserta didik. Diharapkan masing-masing peserta didik dapat menunjukkan perubahan yang sifatnya positif dan di akhir pendidikan mendapatkan keterampilan, pengetahuan dan kecakapan untuk menyelesaikan permasalahan yang dihadapinya baik dalam kehidupan sehari-hari maupun dalam pendidikan lanjut.

Alan Mortiboys (2005) di dalam bukunya Teaching with Emotional Intelligence mengatakan bahwa pengajar membawa dua hal penting ke dalam kelas yang dapat memberikan nilai bagi peserta didik, yaitu keahlian atau kedalaman pengetahuan pengajar dalam subjek yang diajarkannya dan pengetahuannya akan metode belajar mengajar. Namun selain kedua hal tersebut, Alan percaya bahwa kecerdasan emosi merupakan salah satu hal yang juga penting dikembangkan oleh pengajar dan diaplikasikan ketika memberikan pengajaran di dalam kelas.

Kecerdasan emosi menjadi penting karena pada dasarnya dalam proses belajar tercakup daya juang, frustrasi, sensasi atau kegembiraan. Dalam proses belajar mengajar di kelas, selain terdapat dinamika antara pengajar dan peserta didik atau antara peserta didik dan peserta didik lainnya, juga terdapat persepsi baha sukses dan gagal adalah dua kemungkinan yang bisa terjadi. Oleh karena itu kekuatan perasaan yang terjadi dalam proses belajar mengajar sangatlah tinggi. Berkaitan dengan tugas dan tanggungjawab pengajar untuk membantu peserta didik mempelajari sesuatu, maka seorang pengajar diharapkan mampu mengenali dimensi-dimensi emosional dalam proses belajar. Hal ini mendorong seorang pengajar untuk dapat menggunakan kecerdasan emosinya.

\section{Emotional Intelligence}

Emotional Intelligence atau kecerdasan emosi dapat diartikan sebagai kemampuan untuk mengenali dan mengatasi emosi yang dirasakan oleh diri sendiri ataupun orang lain (Mortiboys, 2005). Istilah kecerdasan emosi sendiri dipopulerkan oleh Daniel Goleman pada tahun 1995 melalui buku Emotional Intelligence : Why it can matter more than IQ. Goleman mendefinisikan kecerdasan emosi sebagai kapasitas untuk mengenali perasaan yang dialami diri sendiri dan orang lain, untuk dapat memberikan motivasi kepada diri sendiri, mengatur emosi dengan baik terhadap diri sendiri maupun terhadap relasi dengan orang lain (Mortiboys, 2005).

Lima kompetensi sosial dan emosional yang diidentifikasikan oleh Goleman (Mortiboys, 2005) adalah (1) self-awareness, waspada terhadap apa yang dirasakan terhadap diri sendiri; (2) self regulation, mampu mengatur perasaan yang dialami; (3) motivation, mampu menggunakan perasaan yang dialami untuk mencapai tujuan; (4) empathy, memahami apa yang dirasakan oleh orang lain; (5) social skills, mampu mengatasi perasaan dengan baik ketika berinteraksi dengan orang lain.

Untuk mengembangkan dan mengaplikasikan kecerdasan emosi, seorang pengajar diharapkan untuk memiliki dua tujuan, yaitu mampu mengenali dan memberikan respon terhadap perasaanperasaan yang dirasakannya baik oleh dirinya maupun oleh peserta didik di dalam kelas agar kedua belah pihak dapat dengan efektif menjalankan perannya masing-masing dan mendorong emosi yang dirasakan oleh peserta didik agar kondusif untuk belajar. 
Mengajar dengan kecerdasan emosi menuntut seorang pengajar untuk bukan hanya mendalami materi pelajaran yang akan diajarkan namun juga mempersiapkan diri untuk dapat lebih fleksibel dan siap memberikan respon terhadap peserta didik di dalam kelas. Selain itu, diharapkan seorang pengajar bukan hanya menyiapkan energi untuk menyusun materi dan metode mengajar, namun juga menyiapkan energi untuk bertemu dengan peserta didiknya. Pengembangan atau penambahan ilmu pengetahuan untuk dirinya diharapkan bukan saja dalam materi pelajaran namun juga meningkatkan pengetahuannya untuk mengembangkan kepribadiannya. Persepsi peserta didik juga akan berubah jika pengajar di dalam kelas mampu menggunakan kecerdasan emosi. Jika peserta didik mendapatkan perhatian dan juga merasa dihargai oleh pengajar maka hal ini dapat merubah cara pandang mereka terhadap pengajar.

\section{PEMBAHASAN}

\section{Aplikasi Emotional Intelligence dalam Proses Belajar}

\section{Mengembangkan Self Awareness}

Di dalam lima kompetensi sosial dan emosional yang dikemukakan oleh Daniel Goleman, self-awareness merupakan kompetensi yang pertama dituliskannya. Hal ini menunjukkan bahwa kompetensi yang pertama ini merupakan dasar dari empat kompetensinya yang lain. Goleman mendefinisikan self-awareness sebagai pengetahuan akan apa yang dirasakan pada suatu waktu, kemudian menggunakan apa yang diketahuinya itu untuk menuntun proses pengambilan keputusan dan; memiliki pengukuran yang realistis terhadap kemampuan diri dan memiliki rasa percaya diri yang sesuai dengan kemampuannya (Motiboys, 2005). Alan Mortiboys mengemukakan bahwa terdapat tiga tingkatan yang berguna untuk mengembangkan self-awareness sebagai pengajar adalah kesadaran akan perasaan yang dialami pada suatu waktu pada saat mengajar, kesadaran akan nilai dan sikap sebagai seorang pengajar, dan kesadaran akan perilaku seorang pengajar dan bagaimana individu lain memaknainya.

Kesadaran akan perasaan yang dialami oleh diri sendiri pada saat mengajar sangatlah signifikan untuk menggunakan kecerdasan emosi di dalam proses seorang pengejar mengajar. Pengajar akan dapat menyesuaikan diri dengan perasaan orang lain jika ia juga dapat menyesuaikan diri dengan perasaan yang dialaminya. Setelah seorang individu dapat mengenali dan menerima apa yang ia rasakan, maka barulah ia dapat memahami apa yang dirasakan oleh individu lain. Hal ini juga mendorong seorang pengajar untuk dapat belajar melalui hasil refleksi diri terhadap dirinya sendiri bukan hanya untuk menggunakan kecerdasan emosi pada saat mengajar namun juga untuk kesuksesan pengajar dalam mengembangkan kepribadiannya.

Seorang pengajar juga perlu untuk waspada terhadap karakter sebagai bagian dari nilai dan juga sikap yang ditampilkan. Karakter yang ditampilkan oleh pengajar akan mempengaruhi bagaimana relasi yang akan dibangun antara pengajar dan peserta didik. Oleh karena itu, mengenali diri sendiri sangatlah penting karena akan membantu pengajar untuk dapat mengenali dan memahami orang lain.

Selain karakter, seorang pengajar juga perlu mempertimbangkan perilaku yang ia tampilkan di depan orang lain. Perilaku ini mencakup bagaimana seorang pengajar bertingkah laku, bagaimana cara berbicara, kebiasaan-kebiasaan yang dimiliki dan juga komunikasi non-verbal. Kesadaran ini menjadi penting karena untuk dapat mempengaruhi kesiapan belajar peserta didik, pengajar perlu mengetahui bagaimana peserta didik melihat dan menilai perilaku pengajar dan bagaimana pengaruhnya terhadap mereka. 
Pengembangan self-awareness atau kesadaran akan perasaan yang dirasakan oleh diri sendiri bukanlah sesuatu yang mudah. Beberapa hal yang perlu diingat agar pengajar menyadari perasaannya adalah (Mortiboys, 2005), yaitu jujurlah terhadap diri sendiri; jangan terlalu cepat menilai, fokus pada bagaimana mengekspresikan dan mengenali perasaan-perasaan diri sendiri; temukan waktu dan tempat yang paling nyaman untuk bisa mengeksplorasi diri, dapat juga mencari atau meminta bantuan dari teman yang dapat mendukung; dan jika bisa, terimalah apa adanya apa yang ditemukan ketika mengeksplorasi diri tanpa menilai diri sendiri.

\section{Mengenali dan Mengatasi Perasaan}

Pengajar diharapkan untuk dapat mengenali dan mengatasi perasaan-perasaan yang dirasakan oleh peserta didik. Namun pada dasarnya, perasaan-perasaan yang dirasakan oleh pengajar juga butuh dikenali dan diatasi. Mengatur perasaan termasuk dalam lima kompetensi sosial dan emosional yang dikemukakan oleh Daniel Goleman. Kemampuan ini menjadi penting apabila pengajar mengalami perasaan yang cenderung negatif seperti marah atau takut dan keputusan yang diambil untuk merespon perasaan-perasaan tersebut haruslah keputusan yang terbaik.

Beberapa hal penting yang perlu diperhatikan untuk mengatasi perasaan-perasaan yang dialami pengajar (Martiboys, 2005) adalah mengenali perasaan-perasaan tersebut, mengatur perasaan sehingga pengajar dapat memilih bagaimana akan berperilaku, dan memastikan mampu mengambil waktu untuk merenung, merefleksikan dan belajar dari pengalaman. Hal ini akan membantu pengajar untuk dapat mengatasi perasaan-perasaan yang dialaminya karena ketika individu menyadari apa yang dirasakannya, saat itu juga keputusan harus diambil untuk mengatasi atau memberikan respon terhadap perasaan yang dialami tersebut.

\section{Relasi dengan Peserta Didik}

Sebagai bagian dari self-awareness yang merupakan langkah pertama untuk dapat menggunakan kecerdasan emosi ketika mengajar, sangatlah penting bagi seorang pengajar untuk dapat menyadari bagaimana kecenderungannya untuk berinteraksi dengan peserta didik. Bagaimana seorang pengajar berelasi dan berinteraksi dengan peserta didik akan membuat para peserta didik secara langsung memaknai apa yang mereka rasakan sepanjang sesi pengajaran, mempengaruhi persepsi peserta didik yang menentukan perilaku seperti apa yang akan mereka tunjukkan di dalam kelas dan juga akan menjadi parameter bagi pengajar untuk mengukur kecerdasan emosi yang digunakannya di dalam kelas (Mortiboys, 2005).

Kecenderungan pengajar untuk menunjukkan siapa dirinya ketika berinteraksi dengan peserta didik akan berpengaruh pada relasi yang akan dibentuk, kedalaman relasi, keterbukaan dan juga kepercayaan peserta didik kepada pengajar (Mortiboys, 2005). Pengajar diharapkan dapat mengeksplorasi sejauh mana ia dapat memilih peran yang tepat ketika berelasi dengan peserta didik. Secara spesifik, jika pengajar mampu menciptakan relasi saling percaya dengan peserta didik maka hal ini akan mempengaruhi setiap aktifitas di dalam kelas. Hal ini juga akan mempengaruhi bagaimana peserta didik akan bertingkah laku di dalam kelas, bagaimana peserta didik melihat dan memberikan respon terhadap materi - materi yang diberikan di dalam kelas. Keuntungan lain bagi pengajar adalah pengajar dapat lebih fleksibel untuk menentukan pendekaran kepada para peserta didik. Jika pengajar ingin mencoba sesuatu yang baru, peserta didik akan lebih mudah mengikuti karena mereka percaya kepada pengajar.

Selain kecenderungan dalam berinteraksi dengan peserta didik, pengajar juga perlu lebih menyadari personal style yang dimilikinya. Personal style atau yang juga disebut dengan ego-state adalah bagian dari teori Transactional Analysis yang dipelopori oleh Eric Berne (Barker, 1980). Transactional Analysis adalah teori kepribadian dan juga teori komunikasi yang memperhatikan apa yang terjadi dalam relasi diantara individu (Barker, 1980). Personal style atau ego-state 
menggambarkan apa yang dipikirkan, dirasakan dan ditunjukkan melalui tingkah laku oleh seorang individu pada suatu waktu (Mortiboys, 2005). Terdapat tiga kategori di dalam Personal style, yaitu Parent, Adult dan Child (Berne, 1964). Ketika seorang individu menggunakan personal style Parent maka ia akan berpikir, merasa dan bertingkah laku selayaknya orangtua yang diserap oleh individu tersebut dari peran orangtua atau individu yang signifikan dalam masa pertumbuhannya. Ketika seorang individu menggunakan personal style Adult maka pemikiran, perasaan dan perilaku kan didasarkan pada apa yang terjadi saat ini bukan berdasarkan masa lalu. Ketika seorang individu menggunakan personal style Child, maka individu tersebut memainkan kembali pikiran, perasaan dan perilaku dari masa kecil.

Ketiga personal style ini mempengaruhi bagaimana komunikasi yang terjadi antara pengajar dan peserta didik. Setiap individu memiliki kecenderungan sendiri untuk menunjukkan personal style masing-masing pada suatu saat. Personal style menjadi penting karena dapat saja seorang peserta didik menggunakan personal style Child dengan harapan pengajar menggunakan personal style Parent agar tujuannya tercapai, namun yang terjadi adalah pengajar menggunakan personal style Adult sehingga kesalahpahaman komunikasi terjadi.

\section{Menciptakan Iklim Kelas yang Kondusif}

Seorang pengajar diharuskan untuk merencanakan apa saja yang akan dilakukan di dalam kelas. Bukan hanya merencanakan metode pengajaran atau peraturan yang akan dijalankan di dalam kelas, namun juga diharapkan merencanakan ikilm atau suasana kelas seperti apa yang akan diciptakan. Suasana kelas yang diciptakan ini akan mempengaruhi kesiapan peserta didik untuk menerima pelajaran. Kelas yang diatur dengan baik ditandai dengan peserta didik yang terdapat di dalam kelas secara aktif dan konsisten terlibat dalam aktivitas belajar yang produktif dan perilaku dari peserta didik jarang mempengaruhi pencapaian tujuan instruksional (Brophy, 2006; W. Doyle, 1990; Emmer \& Everston, 1981 dalam Omrod, 2008). Kelas yang diatur secara efektif serupa dengan pola asuh authoritative dari orangtua dimana orang tua cenderung menyediakan suasasana yang hangat dan mendukung, memberikan standard yang cukup tinggi atas perilaku anak, menjelaskan perilaku apa saja yang dapat diterima dan mana yang tidak, secara konsisten mendorong jalannya peraturan di dalam rumah, melibatkan anak ketika memutuskan sesuatu, dan memberikan kesempatan untuk anak dapat mandiri.

Selain beberapa hal di atas, kesiapan peserta didik untuk menerima pelajaran juga dipengaruhi oleh suasana atau lingkungan emosional (Mortiboys, 2005). Lingkungan emosional ini merupakan pengalaman secara keseluruhan yang dialami oleh peserta didik di dalam kelas. Beberapa faktor yang dapat mempengaruhi lingkungan emosional adalah (Mortiboys, 2005), yaitu perilaku yang ditampilkan oleh pengajar, perilaku yang ditampilkan oleh peserta didik, pengalaman fisik yang dialami oleh peserta didik, bahasa yang digunakan oleh pengajar, material atau bahan ajar yang ada dan bagaimana keefektifan penggunaan material tersebut, dan aktivitas dimana setiap peserta didik dapat terlibat di dalamnya. Lingkungan emosional yang baik akan memberikan pengaruh dimana peserta didik merasa aman dan tidak terancam dengan pengajar, percaya sepenuhnya kepada pengajar, merasa tertantang untuk mengeksplorasi banyak hal dan bukan tertekan, serta termotivasi untuk belajar.

\section{SIMPULAN}

Dapat disimpulkan bahwa dalam mempersiapkan kegiatan belajar mengajar, seorang pengajar dituntut untuk dapat melihat proses belajar mengajar secara keseluruhan. Persiapan yang dilakukan bukan hanya untuk materi yang akan dibawakan dan metode mengajar yang akan diterapkan, namun kecerdasan emosi seorang pengajar juga penting untuk dikembangkan agar dapat menciptakan dan menghasilkan mutu pendidikan yang baik. Kompetensi sosial dan emosional yang pertama dari 
kecerdasan emosi yang perlu dikembangkan adalah self-awareness atau kesadaran diri akan perasaan perasaan yang dialami. Dengan mengembangkan kompetensi ini, pengajar akan dapat memilih keputusan apa yang tepat untuk mengatasi hal-hal yang terjadi di dalam kelas yang berkaitan dengan emosi diri sendiri maupun peserta didiknya. Pengajar juga akan dengan mudah mengenali perasaanperasaan yang dirasakan oleh peserta didik apabila ia juga dapat mengenali dan menerima apa yang ia rasakan.

Hubungan dengan peserta didik juga merupakan salah satu faktor yang dapat mempengaruhi proses belajar yang efektif di dalam kelas. Pertama, pengajar perlu menyadari peran seperti apa yang akan ia tunjukkan kepada peserta didik di dalam kelas. Peran ini akan mempengaruhi bagaimana peserta didik merasa dan menilai pengajar. Pada dasarnya, gaya pribadi setiap pengajar pasti berbeda, yang terpenting adalah bagaimana pengajar dapat mengenali gaya pribadi yang paling efektif untuk ditampilkan kepada peserta didik sesuai dengan kepribadian para peserta didik. Selain pengelolaan di dalam diri, bagaimana pengajar mengelola kelas akan mempengaruhi suasana yang tercipta di dalam kelas. Suasana yang tercipta ini membutuhkan banyak faktor agar dapat mempersiapkan peserta didik untuk menerima pelajaran. Hal terpenting dalam pengelolaan kelas ini adalah pengajar perlu mengukur konsistensi dan keaktifan peserta didik untuk terlibat dalam proses belajar. Keterlibatan peserta didik ini juga dipengaruhi oleh rasa aman, rasa percaya dan motivasi dari peserta didik untuk aktif di dalam kelas. Sikap dan perilaku pengajar akan mendorong perasaan-perasaan ini untuk muncul dari peserta didik. Secara umum, dapat dikatakan bahwa emotional intelligence atau kecerdasan emosi memiliki beragam manfaat bagi pengajar untuk dapat menjalani proses belajar mengajar dengan lebih efektif. Kesadaran akan hal inilah yang perlu ditumbuhkan bagi para pengajar sehingga pengajar tidak hanya mengalokasikan energi yang dimiliki semata-mata untuk hal-hal yang bersifat materi dan metode saja namun juga mempersiapkan energi untuk berelasi dengan peserta didik.

\section{DAFTAR PUSTAKA}

Barker, D. (1980). TA and Training. The Theory and Use of Transactional Analysis in Organisations. England: Gower Press.

Berne, E. (1964). Games People Play. The Psychology of Human Relationship. England: Penguin Books.

Mortiboys, A. (2005). Teaching with Emotional Intelligence. A step-by-step guide for higher and further education professionals. Oxon: Routledge.

Omrod, J. E. (2008). Educational Psychology. Developing Learnes. New Jersey: Pearson Education Inc. 